\title{
A construção da masculinidade e a banalidade do mal: outros aspectos do trabalho escravo contemporâneo*
}

\author{
Patrícia Trindade Maranhão Costa**
}

\begin{abstract}
Resumo
O texto estimula a discussão e a reflexão sobre outros aspectos que envolvem a escravidão contemporânea no Brasil: o processo de construção da masculinidade que permeia a partida dos jovens trabalhadores rurais que acabam enredados no endividamento progressivo e, paralelo a este, o processo de desenraizamento social, que apaga os laços com a família deixada para trás e com os lugares de origem desses jovens trabalhadores. Isso acentua sua vulnerabilidade e contribui para que suas vidas sejam destituídas de valor político e importância social.
\end{abstract}

Palavras-chave: Escravidão Contemporânea, Masculinidade, Banalidade do Mal.

\footnotetext{
* Recebido para publicação em agosto de 2008, aceito em setembro de 2008. Este artigo é resultado de minha experiência enquanto colaboradora externa da OIT, entre março e junho de 2008, cujo objetivo foi elaborar um estudo de caso sobre as ações desenvolvidas no Brasil para combater o trabalho escravo contemporâneo. Agradeço a leitura atenta e as valiosas contribuições de Adriana Piscitelli, Mireya Suárez, Marcia Vasconcelos e Cristhian da Silva. Obviamente, eventuais enganos e falhas são de minha inteira responsabilidade.

** Doutora em Antropologia Social pela Universidade de Brasília, pesquisadora independente.patriciatmcosta@gmail.com
}

cadernos pagu (31), julho-dezembro de 2008:173-198. 
A construção da masculinidade e a banalidade do mal

The Construction of the Masculinity and the Banality of Evil:

Other Aspects of the Contemporary Slave Work

\begin{abstract}
The text stimulates a reflection and discussion about other aspects concerning contemporary slavery in Brazil: the process of constructing masculinity carried out by young male rural workers who leave their family home to search for work and run into debt, together with the process of social uprooting that eliminates links with the family left behind and with the place of origin of these young men. Those processes increase their vulnerability and contribute to making their lives devoid of political value and social importance.
\end{abstract}

Key Words: Contemporary Slavery, Masculinity,

Banality of Evil. 
As reflexões aqui apresentadas foram suscitadas pelo estudo realizado, a pedido da OIT-Brasil, sobre as ações brasileiras no combate ao trabalho escravo contemporâneo. Em fase de revisão e com publicação prevista para 2009, o estudo baseou-se, principalmente, em pesquisa bibliográfica por meio da consulta a textos acadêmicos relativos ao tema $e$ documentos disponibilizados por diversas fontes, como a OIT e entidades parceiras do Projeto Técnico de Combate ao Trabalho Escravo no Brasil. Também foram realizadas consultas a pesquisadores $e$ profissionais que atuam em diferentes órgãos envolvidos no desenvolvimento do projeto. ${ }^{1}$

Dentre as fontes utilizadas no estudo, o livro de Ricardo Rezende Figueira (2004) foi uma referência central para pensar o trabalho escravo contemporâneo. Além de descrever e analisar aspectos estruturais e conjunturais do problema, o autor apresenta inúmeros relatos de trabalhadores que foram submetidos a condições análogas à escravidão, citando diferentes formas de violência que podiam afetá-los. Um exemplo marcante refere-se ao caso de um trabalhador escravizado que, após uma tentativa de fuga, foi capturado por um funcionário da fazenda em que trabalhava. Como punição, ele foi obrigado a realizar sexo oral nesse funcionário diante de todos os trabalhadores.

A pesada carga simbólica desse ato gerou indagações sobre os diferentes fatores que parecem viabilizar esse tipo de abuso sofrido pelos trabalhadores rurais, seja por parte de quem exerce a violência ou de quem a sofre. Nesse sentido, este artigo busca estimular a discussão e a reflexão sobre alguns aspectos "impensados" que envolvem o tema da escravidão contemporânea, como o processo de construção da masculinidade, que permeia a partida dos jovens que acabam

1 Dentre as instituições consultadas destaco: Comissão Pastoral da Terra (CPT), ONG Repórter Brasil, Grupo de Estudo e Pesquisa sobre o Trabalho Escravo Contemporâneo (GPTEC) da Universidade Federal do Rio de Janeiro (UFRJ), Instituto Carvão Cidadão (ICC), Instituto Observatório Social (IOS) e Ministério do Trabalho e Emprego (MTE). 
A construção da masculinidade e a banalidade do mal

enredados nas teias do aliciamento e do endividamento que os prendem a condições degradantes de trabalho e, paralelamente, o processo de desenraizamento social, no qual, aos poucos, são apagados os laços com a família deixada para trás e com os lugares de origem desses jovens trabalhadores.

É o primeiro processo que viabiliza o tráfico interno de pessoas que tem por finalidade o trabalho forçado. O segundo processo, decorrente do tráfico, contribui para a desvalorização social dos trabalhadores escravizados, acentuando sua vulnerabilidade. Se, em um primeiro momento, a pobreza privava suas vidas de valor político e importância social, após a escravidão suas vidas tornam-se completamente nuas, para usar o termo de Agamben (2002), sobretudo, aos olhos daqueles que os escravizam. Enquanto vidas nuas, elas são matáveis e passíveis de toda forma de violência, sem que isso acarrete grandes questionamentos morais por parte dos que a exercem. A morte dos trabalhadores $e$ a violência contra eles tornam-se, desse modo, práticas banais e corriqueiras intrínsecas às atividades das fazendas para onde os jovens são levados.

Desconstruir esses processos permite entender dois importantes atores sociais envolvidos no trabalho escravo contemporâneo: o trabalhador escravizado, analisado na figura do jovem que parte da casa dos pais, e o perpetrador da violência contra o trabalhador, na figura do fazendeiro. Pretende-se, desse modo, analisar processos inerentes à escravidão contemporânea considerando aspectos culturais de alguns sujeitos nela envolvidos.

Para tanto, primeiro será apresentado o problema do trabalho escravo contemporâneo, tendo em vista o perfil do trabalhador escravizado e o processo de aliciamento dos jovens, que implica intenso tráfico de pessoas do Nordeste brasileiro para fazendas situadas, sobretudo, no Norte do país.

A partir dessas informações, serão apresentadas algumas causas estruturais da escravidão contemporânea, o que permite entender o lugar de homens e mulheres nesse quadro. Entre essas causas, como parte de um movimento que culmina na escravidão, 
ressalto o processo de construção da masculinidade e aquisição da maioridade por parte dos jovens que saem da casa dos pais para fugir da pobreza, bem como em busca de aventura e dinheiro com vistas a se tornar um dia o pai-provedor.

Enredar-se nas teias do aliciamento, por sua vez, gera o desenraizamento social desses jovens, tornando-os não-cidadãos $e$, por isso, passíveis de violência e de situações de trabalho que os privam das condições mínimas de sobrevivência e dignidade. A banalidade do mal a que os trabalhadores escravizados são submetidos parece guardar semelhanças com a lógica, analisada por Machado (2000), por trás da violência sexual exercida contra as mulheres. Os dois casos parecem ser parte de um cenário maior marcado pela politização da vida, comum a todas as sociedades, no qual um poder soberano, personificado na figura do homem, no caso das mulheres, ou do patrão, no caso dos trabalhadores escravizados, pode decidir impunemente quais vidas deixam de ser politicamente relevantes e quando elas podem ser eliminadas ou submetidas à violência.

\section{O problema do trabalho escravo contemporâneo}

A "Pesquisa sobre o Perfil dos Principais Atores Envolvidos no Trabalho Escravo Rural", financiada pela OIT-Brasil e realizada pelo Grupo de Estudo e Pesquisa sobre o Trabalho Escravo Contemporâneo (GPTEC) da Universidade Federal do Rio de Janeiro (UFRJ), constatou que o trabalhador rural escravizado no Brasil é, quase na totalidade dos números, do sexo masculino, não-branco e com nível de escolaridade muito baixo. Cerca de $20 \%$ nunca chegou a freqüentar escola, $85 \%$ nunca fez nenhum tipo de curso profissional, ainda que $81 \%$ tenha declarado que gostaria de fazê-lo (OIT, no prelo).

Sua ocupação predominante tem sido o trabalho rural temporário sem registro (ou carteira de trabalho). Quanto às atividades desempenhadas, o estudo realizado pela ONG Repórter Brasil revelou que $62 \%$ dos trabalhadores escravizados no Brasil 
A construção da masculinidade e a banalidade do mal

destinam-se às atividades ligadas à criação de gado, $18,6 \%$ à produção de grãos (soja, algodão, milho, arroz, feijão, café) e $12 \%$ à produção de carvão. De modo geral, os trabalhadores são empregados em tarefas não-especializadas - derrubada da mata nativa, realização da roça de "juquira" ${ }^{2}$ limpeza de terreno para plantação de lavoura, colheita de cana-de-açúcar, plantação de grãos, produção de carvão vegetal, entre outras.

Vale destacar que a pesquisa realizada pelo GPTEC focalizou o conjunto de trabalhadores escravizados resgatados pelo Grupo Especial de Fiscalização Móvel (GEFM) do Ministério do Trabalho e Emprego (MTE), responsável pela apuração in loco das denúncias de trabalho escravo, entre outubro de 2006 a julho de 2007. ${ }^{3}$ A investigação baseou-se em uma metodologia qualitativa, de modo a não pretender uma representação estatística integral da situação.

Nesse sentido, os dados permitem vislumbrar o perfil geral do trabalhador escravizado no Brasil a partir do perfil do trabalhador resgatado pelo grupo móvel nesse período. Isso tem revelado que, de modo geral, o trabalhador escravizado é originário da Região Nordeste, sobretudo do estado do Maranhão. Em busca de trabalho, ele dirige-se ou é levado para fazendas no Pará e no Mato Grosso, principalmente, embora também possa vir a compor o contingente de trabalhadores de fazendas na Bahia $e$ em Goiás.

Ainda que seja rara a presença de mulheres nas fazendas, elas aparecem constantemente nas narrativas dos trabalhadores

\footnotetext{
2 "Juquira" consiste na limpeza de um mato denso que cresce na área anteriormente derrubada e formada em pasto. Utiliza-se como instrumento de trabalho a foice. Se a quantia de mato for pequena, sua limpeza pode ser chamada de "juquirinha", se grande, "juquirão" (Figueira, 2004:17).

3 Vale ressaltar que o Grupo Especial de Fiscalização Móvel (GEFM) pertence ao Ministério do Trabalho e Emprego (MTE), mas conta com a participação funcionários do Ministério Público Federal (MPF) e de agentes da Polícia Federal (PF) nas suas equipes para realizar a apuração das denúncias de trabalho escravo nas fazendas situadas no interior do país.
} 
resgatados, como revelou Figueira (2004:84). Assim, elas surgem na figura de mães, avós, madrinhas, filhas e, mais raramente, na de esposas, já que a maior parte não tem companheira. Todas viveram as aflições do trabalho escravo pela falta de notícias sobre o paradeiro dos que partiram. Além disso, as mulheres podem aparecer na figura daquelas que estabeleceram alianças precárias com os funcionários das fazendas para onde os jovens são levados, ou ainda, nas donas de pensões e prostíbulos situados nos municípios em que os trabalhadores podem ser cooptados para o trabalho escravo.

Normalmente, o trabalhador escravizado é jovem, com idade superior a 16 anos e quando resgatado possui, em média, 31 anos. Eles vêm do meio rural e são filhos de pequenos agricultores pobres (Martins, 1997:106). A precária situação econômica pressiona a família que, sem condições de manter todos os membros, transforma a procura por trabalho em outros lugares uma necessidade. Partir não resolve o problema, mas ficar também não ajuda, pois não há oferta de emprego suficiente, sobretudo no meio rural da Região Nordeste, normalmente assolada pela seca. Quando há terra, não existem condições de produzir e comercializar, a exemplo dos assentamentos rurais criados pelo INCRA no final da década de 1990 que não tinham condições mínimas de funcionamento, como revelou Figueira (2004).

O trabalhador parte em busca de oportunidades de trabalho a fim de superar uma situação de penúria ou fome. Entretanto, ele também parte na esperança de ficar rico, para fugir de conflitos familiares, normalmente ocorridos com o pai, para manifestar a virilidade ou o companheirismo, pelo sonho de viver uma aventura em terras estranhas e pelo desejo de tornar-se o provedor de um lar.

Impulsionado por tais desejos, sozinho ou em grupos, os jovens são recrutados $e$ aliciados por fazendeiros ou por um preposto dos fazendeiros, chamado "gato". Ainda nas suas cidades ou em outros municípios, eles são convidados a trabalhar 
A construção da masculinidade e a banalidade do mal

em regiões distantes de seu domicílio, mediante promessas enganosas de emprego e salário, normalmente, com um preço acordado por hectare a ser trabalhado. Ao chegar à fazenda, percebem que o trabalho, em geral, é muito mais duro que o antecipado. Eles descobrem também ter contraído uma dívida junto ao "gato" referente às passagens, ao que foi consumido durante a viagem e ao salário adiantado concedido ao trabalhador para deixar a família abastecida durante sua ausência.

Nas fazendas, eles são submetidos a um contínuo endividamento. Todo material consumido referente à alimentação $e$ à moradia deve ser comprado a um preço superfaturado nas próprias fazendas. Essa é a chamada "política do barracão" ou truck system (Melo, 2007:68).

O pagamento deve ser realizado por meio dos proventos a serem recebidos pelo trabalhador, que só poderá deixar a fazenda quando a dívida estiver quitada. $\mathrm{O}$ isolamento da fazenda em relação a qualquer tipo de transporte dificulta as possibilidades de fuga. Somado a isso, para que as fugas sejam evitadas, os trabalhadores podem ter seus documentos retidos, bem como são constantemente vigiados e ameaçados por funcionários armados, constituindo uma situação degradante de trabalho e cerceadora da liberdade dos trabalhadores. As condições de alimentação e moradia também são precárias. Muitos dormem fechados $e$ trancados em barracões feitos de lona e cercados de palha $e$, seguidas vezes, sem acesso à comida e água potável.

\section{O aliciamento como tráfico interno de pessoas}

Antes de prosseguir a análise, é necessário contextualizar a questão do tráfico de pessoas que compõe o cenário do trabalho escravo contemporâneo. Diante do exposto, a migração é uma das características mais presentes na escravidão por dívida, visto que $74 \%$ das vítimas não vivem no município em que nasceram $e$ $40 \%$ moram em estados diferentes do local de origem. O maior número de trabalhadores resgatados entre 1995 e 2007 estava em 
fazendas no Pará (37\%) e no Mato Grosso (20,1\%). Parte significativa saiu de seu município para trabalhar nos dois últimos anos e $32 \%$ foram trabalhar em outro estado.

O aliciamento a que os trabalhadores são submetidos é o catalisador do tráfico interno de pessoas que afeta o meio rural brasileiro. Internacionalmente, o tráfico de pessoas está relacionado ao trabalho forçado contemporâneo, à medida que, em diferentes países, a prática visa fornecer mão-de-obra para esse tipo de trabalho. Esse é o caso, principalmente, da exploração sexual de mulheres vindas de diferentes partes do mundo para países da Europa. Para enfrentar as dimensões do tráfico que resulta no trabalho forçado, vários Estados-Nacionais adotaram uma nova legislação, de modo a atender as prerrogativas estabelecidas pelo Protocolo de Palermo para prevenir, eliminar e punir o tráfico de pessoas, especialmente de mulheres e crianças (OIT, no prelo).

No Brasil, o tráfico de pessoas atende a diferentes propósitos, entre eles a escravidão de trabalhadores. Por isso, o Protocolo de Palermo ou "Protocolo do Tráfico" foi ratificado em março de 2004 pelo Estado brasileiro. A definição de tráfico de seres humanos, contida no Protocolo, guarda inúmeras semelhanças com o aliciamento dos trabalhadores rurais escravizados no Brasil:

(...) A expressão "tráfico de pessoas" significa o recrutamento, o transporte, a transferência, o alojamento ou o acolhimento de pessoas, recorrendo à ameaça ou uso da força e outras formas de coação, ao rapto, à fraude, ao engano, ao abuso de autoridade ou à situação de vulnerabilidade ou à entrega ou aceitação de pagamento ou benefícios para obter o consentimento de uma pessoa que tenha autoridade sobre outra para fins de exploração sexual, o trabalho ou serviços forçados, escravatura ou práticas similares à escravatura, a servidão, ou a remoção de órgãos... (Relatório Global, 2005). 
A construção da masculinidade e a banalidade do mal

No trabalho escravo, o tráfico de pessoas realizado por meio do aliciamento ocorre, especialmente, dentro do território nacional. O combate ao aliciamento na legislação brasileira está caracterizado e previsto no artigo 206 do Código Penal Brasileiro, que pune o aliciamento para fins de emigração, e no artigo 207, que pune o aliciamento para fins de migração interna, impactando, de forma mais imediata, as práticas que levam ao trabalho escravo contemporâneo no país. Assim, o artigo 207 não pune a transferência pacífica de trabalhadores, mas o aliciamento por terceiros com o fim de levá-los de um ponto para outro.

Em um primeiro momento, o aliciador era punido apenas se a vítima fosse transferida para um local distante do seu domicílio. Novas discussões conceituais levaram à conclusão de que pouco importa se os locais de onde saem e para onde vão os trabalhadores são distantes entre si. Admitiu-se também que, para ser punido, o aliciamento pode ser realizado por qualquer meio, não sendo necessário o uso de fraude.

Desse modo, o artigo 207 foi modificado pela lei $n^{\circ}$ 9.777/98, punindo quem recruta trabalhadores fora do local de execução do trabalho, dentro do território nacional, mediante fraude ou cobrança de qualquer quantia ao trabalhador. Pune também quem alicia o trabalhador em local diverso daquele em que o serviço será realizado, mesmo sem o emprego de fraude ou cobrança de qualquer valor, mas que não assegura o retorno do trabalhador ao local de origem. Essa especificação é fundamental no combate ao trabalho escravo, uma vez que é muito comum o abandono do trabalhador pelo contratante da mão-de-obra após o término dos serviços (Melo, 2007:82-83). A pena para esses crimes é a detenção de 1 (um) a 3 (três) anos e multa.

A combinação dessas leis com o artigo 149, que pune a prática de reduzir pessoas a condições análogas à escravidão, procura enquadrar os praticantes desse crime em diferentes delitos (aliciamento, escravidão por dívida, etc.), aumentando as chances de punição e condenação dos mesmos. 
Patrícia Trindade Maranhão Costa

\section{A construção da masculinidade}

As informações relativas à família de origem $e$ aos sonhos $e$ desejos do jovem que parte em busca de trabalho revelam que a viagem é parte de um processo de construção da masculinidade, que antecede a partida e deveria se consolidar com a formação de uma nova família, seja no lugar de origem do trabalhador, para o qual ele pode retornar, seja em um novo local.

Enquanto originário do meio rural, o jovem partilha uma visão de mundo baseada em uma lógica camponesa que tem nas categorias culturais "terra", "trabalho" e "familia" os alicerces para a construção de uma ética que orienta suas ações. Nessa lógica, particularmente analisada por Woortmann (1990), o principal objetivo é assegurar a reprodução física e social do grupo doméstico. ${ }^{4}$ Idealmente, isso deve ser garantido pelo "trabalho livre", isto é, desprovido de patrão, em uma terra fértil que assegure a preservação desse modo de vida.

A família é, portanto, o aspecto central na vida do trabalhador rural. O trabalho é visto como uma missão, pois é através dele que a família será mantida. Trabalhar muito para si $e$ em uma terra ampla assegura às novas gerações melhores condições de vida, o que, na lógica camponesa, não tem relação com nível de vida, mas com possibilidades de trabalho no cultivo da terra (Martins, 1997:125). Nesse sentido, a terra e o trabalho, ou melhor, o trabalho na terra é o meio primordial para a preservação da família a partir dessa percepção.

Se esses princípios são compartilhados por todos os membros do grupo doméstico, homens e mulheres, adultos $e$ crianças, eles são particularmente importantes para os homens, chefes de família. Ser capaz de sustentar a família a partir do

\footnotetext{
${ }^{4}$ Neste trabalho, "grupo doméstico" é entendido como grupo de pessoas que pode viver sob o mesmo teto e do trabalho na mesma terra. A "família", por sua vez, é composta por pessoas unidas por laços de parentesco e afinidade. Pode haver diferentes famílias em um grupo doméstico, mas não costuma haver diferentes grupos domésticos em cada família.
} 
A construção da masculinidade e a banalidade do mal

"trabalho livre" na própria terra parece ser o ideal de masculinidade do camponês. Desenvolver tal habilidade (cultivar a terra e a partir dela prover sua família) é parte do processo de aquisição da maioridade, em que o menino torna-se homem, chefe de família.

A pobreza e, sobretudo, a falta de terra dificultam a realização do papel social masculino imputado aos jovens do meio rural. Se o trabalho reproduz a família, buscar trabalho é, em grande medida, assegurar sua reprodução física, social e cultural.

Tanto o trabalhador que parte sozinho em busca de trabalho, quanto o posseiro que migra com a mulher $e$ os filhos em busca de terra almejam garantir a manutenção da família e a preservação de um modo de vida sem patrão. Para o trabalhador que viaja sozinho, esse objetivo poderá ser alcançado no retorno do jovem, quando, com o dinheiro que sonha conseguir, ele poderá adquirir terra e com ela formar sua própria família, na qual ele será o pai e o provedor. No caso dos posseiros, o objetivo da viagem é manter a família unida e próxima, ao mesmo tempo em que ele dribla a falta de perspectiva de futuro no lugar de origem, expressa na ausência de terra ou na impossibilidade de cultivo. Ao assegurar uma propriedade, o pai cumpre o seu dever de garantir aos filhos terra suficiente para que possam, por sua vez, constituir sua família (Martins, 1997:124-126).

Nos dois casos, a viagem visa preservar a família. Para o posseiro, ela é parte da realização do seu papel de pai. Para o jovem, ela é um empreendimento que traz em si um processo de construção da masculinidade. Se há uma lógica econômica por trás desse empreendimento, ela está subordinada à lógica da família (Martins, 1997). O dinheiro a ser obtido pode transformar-se em terra, verdadeira fonte de riqueza, que se constituirá no patrimônio da família.

No entanto, vale destacar, a busca por aventura, que também permeia a partida do trabalhador, parece revelar indícios da afirmação do individualismo entre os jovens do meio rural e do desejo de abrir novos horizontes de vida. Diante disso, muitos 
almejam alcançar os grandes centros urbanos tendo em vista o forte apelo da urbanização e das ofertas do mundo globalizado. Dessa forma, os posseiros analisados por Martins podem estar migrando em busca de terra, mas muitos jovens podem estar à procura de trabalho assalariado em municípios ou nas metrópoles (Suárez, comunicação oral, agosto de 2008). Prover uma família a partir do próprio trabalho, seja este obtido no campo ou na cidade, é um ideal de masculinidade especialmente partilhado pelos homens do meio rural. A busca pela terra ou a procura por um salário são ideais almejados pelos jovens e interrompidos pela escravidão contemporânea.

A partida, que inclui aceitar a proposta do "gato" para trabalhar em terras distantes, constitui-se em meio necessário à futura construção de uma família por parte do jovem que não vê nas terras do pai possibilidades de trabalho, sendo, assim, privado da realização plena do papel masculino que lhe foi culturalmente atribuído. $\mathrm{O}$ processo para a construção desse papel parece ter início nos conflitos familiares entre o jovem $e$ a autoridade paterna, o que pode ser apontado como "razões subjetivas" da partida (Figueira, 2004). A viagem é o momento de ruptura entre os pais e os filhos homens, além de ser o início de uma nova vida familiar e o meio para realizar o processo de construção da masculinidade. Contudo, são as possibilidades de formação de uma família (na cidade ou no campo) que completarão esse processo.

Ser enredado nas dívidas com o "gato" e acabar aprisionado ao local de trabalho interrompe o processo de aquisição da maioridade, ameaçando a continuidade do grupo doméstico original e cristalizando um ciclo intergeracional de pobreza.

Virilidade e honestidade são aspectos igualmente importantes e presentes nesse processo. Em um primeiro momento, eles impulsionam a partida, em outro, podem acirrar o aprisionamento do trabalhador naquelas condições. 
A construção da masculinidade e a banalidade do mal

A virilidade do jovem que parte se expressa na coragem para empreender uma aventura rumo ao desconhecido. No âmbito da fazenda, a virilidade manifesta-se nas formas de resistência acionadas pelos trabalhadores, uma vez que não aceitam passivamente a relação de exploração. Assim, procuram rejeitar aquilo que consideram abusivo, tentando prejudicar a qualidade do serviço ou fugir. Tais atitudes, no entanto, são acompanhadas de ameaças físicas (OIT, no prelo).

Apesar dessas tentativas, constatam-se dificuldades dos trabalhadores em acionar formas coletivas de resistência. Isso pode ser atribuído à falta de articulação entre os trabalhadores escravizados, uma decorrência deles não conhecerem a fazenda, a região, tampouco os demais grupos de trabalhadores. Além disso, a maioria não tem experiência em ações articuladas, pois, normalmente, não participou de sindicatos, partidos políticos, grupos religiosos ou outras formas de associativismo (Figueira, 2004). Outro motivo é particularmente significativo no aprisionamento desse trabalhador: seu código de ética, que tem na honestidade um valor central.

Assim, ainda que a dívida seja injusta e ilegal, o padrão moral partilhado pelos trabalhadores prescreve que toda dívida deve ser paga, o que atua como uma forma simbólica e eficaz de dominação. A preocupação moral de saldar a dívida aprisiona o trabalhador a si mesmo (ou ao seu código de ética) e aos outros, pois justifica, em alguma medida, a escravidão.

Após meses ou anos, as tarefas para as quais os trabalhadores foram aliciados terminam, mas eles permanecem sem ter como sair da fazenda ou são abandonados nas cidades mais próximas sem nenhum dinheiro. Muitos perdem completamente o contato com o município de origem e com suas famílias, impedindo-os de voltar para casa. Há também os que não voltam por vergonha do insucesso econômico perante a família e da desmoralização a que foram submetidos (Figueira, 2004). 
Sem dinheiro e desligados dos seus laços de amizade $e$ parentesco, os trabalhadores são acolhidos novamente em pequenas pousadas, onde assumem novas dívidas para sobreviver. Suas despesas com hospedagem e alimentação aumentam a cada dia e serão pagas mais uma vez por um "gato" ou um fazendeiro. É reiniciado o ćŕrculo vicioso do endividamento.

Os trabalhadores tornam-se, assim, "peões de trecho" 5 comercializados nas pensões que os acolhem e contabilizam suas dívidas para vendê-los aos aliciadores (Melo, 2006:68). Estabelecese, desse modo, o ciclo da escravidão contemporânea, no qual os trabalhadores permanecem sem se inserir em outra opção de sobrevivência.

$\mathrm{O}$ projeto de construção da masculinidade, interrompido pela escravidão contemporânea, carrega um importante significado identitário, pois reforça o sentimento de pertencimento do trabalhador ao grupo que lhe incutiu os valores e papéis que ele procura realizar por meio da viagem. Além de deter esse projeto, o trabalho escravo gera o isolamento afetivo, econômico e geográfico do trabalhador. Transformado no "peão de trecho", ele é desconectado dos laços sociais que o tornavam parte de um todo que conferia sentido às suas ações. Cativo da rede do endividamento progressivo, o "peão de trecho" personifica, desse modo, o desenraizamento social que acirra a vulnerabilidade do trabalhador e o torna um não-cidadão, destituído de importância social e valor político.

\footnotetext{
5 O "peão de trecho" refere-se ao trabalhador que, sem residência fixa, sobrevive de trabalhos temporários em fazendas. Entre um trabalho e outro, ele permanece em algum município em busca de novas oportunidades, desligado das antigas relações familiares e sem construir novas. Nesse trânsito constante, ele cria débitos em pensões e cabarés, mantendo-se preso à rede de endividamento e ao trabalho coercitivo. Em geral, o "peão-de-trecho" é analfabeto, sem qualificação profissional e tem problemas de alcoolismo. Pode também ser chamado de "peão rodado" (Figueira, 2004:18).
} 
A construção da masculinidade e a banalidade do mal

\section{O processo de desenraizamento social}

O desenraizamento social poderia ser inicialmente pensado como processo que conduz à desumanização do trabalhador escravizado, algo semelhante ao ocorrido na escravidão colonial, quando os escravos negros eram legal e consuetudinariamente percebidos como mercadoria. Na escravidão por dívida, dependendo de situações locais, o trabalhador torna-se mercadoria. Ele pode, por exemplo, ser vendido a outros fazendeiros a pretexto de estar endividado. No entanto, na maior parte dos casos, a dívida é uma forma de assegurar sua permanência no local de trabalho. Isso não necessariamente transforma o "peão" em mercadoria, bem como ele não se constitui em mecanismo de acumulação de capital, como ocorria com os escravos trazidos da África (Martins, 1997:103).

A escravidão colonial, nesse sentido, destituía o escravizado da sua condição humana e essa desumanização era um aspecto central na relação entre escravos e senhores, o que aparece com bastante freqüência nos relatos dos descendentes de escravos da Região do Alto do Paranaíba, oeste de Minas Gerais, com os quais trabalhei na minha pesquisa de doutorado e que lembravam, a partir da memória familiar, a escravidão vivida pelos seus antepassados. $^{7}$

A escravidão contemporânea, por sua vez, não desumaniza o trabalhador, mas, de maneira igualmente problemática, o reduz a um conjunto de estereótipos negativos compartilhado pelos

\footnotetext{
6 "Peão" refere-se a uma categoria comumente utilizada para denominar os trabalhadores escravizados na atualidade. Assim, a categoria designa os trabalhadores rurais em atividades braçais que são levados para os empreendimentos agropecuários na Amazônia, onde devem executar trabalhos pesados, de baixa qualificação profissional, em geral sob coerção (Figueira, 2004:18).

7 Sobre os diferentes aspectos da escravidão colonial que compõem a memória familiar partilhada por descendentes de escravos do Alto do Paranaíba-MG, conferir Costa (2006).
} 
fazendeiros. Isso, em grande medida, justifica a super-exploração e os maus-tratos contra os trabalhadores.

Perigoso, preguiçoso, vingativo, mentiroso, bêbado $e$ desrespeitador das famílias, como apontou Figueira (2004:268), são adjetivos comumente utilizados para qualificar os "peões" $e$, normalmente, acompanham a figura do estranho, do estrangeiro ou daquele que é "de fora". Em outras palavras, são estigmas que acompanham os que estão desconectados dos laços sociais reconhecidos como positivos para um determinado meio. Pelas características do aliciamento, o escravo contemporâneo é migrante, na sua maioria absoluta, portanto, os preconceitos que o afetam parecem ser aspectos inseparáveis do processo de desenraizamento que marca a trajetória dos trabalhadores escravizados, contribuindo para a sua vulnerabilidade.

A exemplo dos imigrantes estrangeiros ilegais e como resultado desse processo, os "peões" não desfrutam dos direitos dos cidadãos. Se antes da partida do jovem trabalhador a pobreza impedia o acesso pleno à cidadania, o desenraizamento social após a escravidão parece eliminar quaisquer chances dele exercer seus direitos. ${ }^{8}$

Quando os laços com a família e com o lugar de origem se afrouxam, o trabalhador tem sua importância social não reconhecida, o que lhe seria atribuído caso ele fosse visto como parte de uma rede de relações sociais específica. Como resultado do desenraizamento social, ele começa a morrer simbólica ou socialmente e esta morte precede a física. A partir desse processo, os trabalhadores tornam-se passíveis da "banalidade do mal", termo elaborado por Hannah Arendt que aborda uma dimensão da maldade que não se enquadra nos padrões usuais da categoria, por exemplo, patologia ou convicção ideológica do

8 Antes da viagem para a Região Norte em busca de trabalho, muitos tinham uma existência legal deficitária, pois não tinham documentos de identidade, nem sequer certidão de nascimento. Torna-se, portanto, uma existência desprovida de direitos, causando uma série de comprometimentos sociais e psicológicos (Figueira: 2004:143) 
A construção da masculinidade e a banalidade do mal

agente. A "banalidade do mal" fala da relação entre o problema do mal e a faculdade de pensar ou à ausência dessa faculdade, pois não se fundamenta na reflexão (Bignoto e Moraes, 2003:144-145).

Nesse sentido, a "banalidade do mal" se aproxima da idéia de superficialidade. As atitudes decorrentes dessa manifestação específica do mal aparecem como triviais ou banais, pois não partem de qualquer estímulo específico, interesse ou volição do perpetrador da maldade, tampouco se enraízam em forças demoníacas do mesmo. O "mal-banal", desse modo, é um fenômeno superficial e extremo. A superficialidade significa que ele não tem raízes na natureza humana ou em motivos maus. Para Hannah Arendt, Eichmann foi a metáfora exata da "banalidade do mal" e o que a impressionava era "o abismo entre a monstruosidade dos atos cometidos $e$ a raiz não-volitiva $e$ superficial do agente" (Arendt apud Bignoto e Moraes, 2003:142).

Diante dessas reflexões, pergunto: o que permite a banalidade do mal por parte dos fazendeiros e seus funcionários em relação aos trabalhadores? Em outras palavras, o que permite que a violência física e psicológica, bem como as condições degradantes de trabalho a que são submetidos os trabalhadores, sejam percebidas, pelos fazendeiros e seus prepostos, como aspectos corriqueiros da atividade produtiva das fazendas?

A banalidade das ações contra os trabalhadores rurais aparece de forma explícita nos discursos dos fazendeiros expressos na mídia. Os relatos não revelam constrangimentos morais quando se referem a essas ações, como demonstra o exemplo abaixo:

J.A. (fazendeiro) ao receber uma jornalista do Le Monde garantiu que não utilizava mão-de-obra escrava. "Manifestou surpresa pela Igreja Católica demonstrar compaixão pelos peões e não por ele, um 'desbaravador', que, com suor construíra um expressivo patrimônio. Sentia-se injustiçado, pois beneficiava os pobres oferecendo trabalho. Para ele tudo era simples: quem deve é obrigado a pagar, mesmo trabalhando sob coerção física; enquanto não saldar a dívida, deve ser retido na fazenda" (Figueira, 2004:317). 
Da mesma forma, quando seus nomes são incluídos na "lista suja", cadastro que agrupa nomes de empregadores (pessoas físicas ou jurídicas) flagrados na exploração de trabalhadores em condições análogas à escravidão, os fazendeiros apresentam-se à Justiça do Trabalho como indivíduos produtivos, altruístas, desbravadores e pioneiros, cujos empreendimentos buscam o crescimento do país por meio da geração de empregos e do pagamento de impostos.

Eles se referem às práticas de trabalho escravo $e$ aos mecanismos de controle e coerção exercidos contra os trabalhadores como "irregularidades trabalhistas" corriqueiras. Desse modo, banalizam o tratamento que os trabalhadores recebem na sua fazenda, bem como podem transferir a responsabilidade do problema para seus funcionários (gerentes $e$ fiscais da fazenda) ou justificar a prática pela necessidade e pela regularidade com que ocorre (Figueira, 2004:303 e 315).

A "banalidade do mal", exemplificada nessas justificativas, não está restrita às relações hierárquicas que permeiam as fazendas, notadamente entre fazendeiros ou seus funcionários $e$ trabalhadores, mas parece ser parte de uma estrutura maior marcada pela politização da vida, em que o corpo é o novo sujeito da política. Essa estrutura, considerada por Agamben (2002) fundamental da modernidade, é denominada como biopolítica. Nela, a vida natural do homem está implicada nos mecanismos e nos cálculos de poder, o que envolve a decisão, estabelecida em toda sociedade, sobre as vidas que deixam de ser politicamente relevantes. Enquanto vidas irrelevantes e, portanto, destituídas de valor e importância social, elas tornam-se nuas e, como tal, podem ser impunemente eliminadas por um poder soberano.

$\mathrm{Na}$ biopolítica moderna, soberano é aquele que decide sobre o valor ou o desvalor da vida (Agamben, 2002:149). O poder soberano, nesse sentido, pode emanar do Estado-Nação, mas pode estar personificado no fazendeiro, cuja soberania, dentro $e$ fora da fazenda, pode ser construída a partir de diferentes fatores. 
A construção da masculinidade e a banalidade do mal

Para manter o regime de servidão e garantir a realização do trabalho, a organização interna das fazendas baseia-se em uma hierarquia que varia segundo a atividade nela desenvolvida (pecuária, lavoura, carvoaria, etc.) e o tamanho da área ocupada. Forma-se, assim, uma cadeia de mando à qual o trabalhador está submetido. Por trás (ou acima) dessa estrutura hierárquica está o proprietário, dono absoluto do poder, assim como, na ponta dessa cadeia de mando, estão as vítimas do aliciamento submetidas a uma intrincada estrutura de coerção (Figueira, 2004:238).

O proprietário da fazenda pode morar em sedes urbanas, fora da propriedade. Quando isso ocorre, ele designa gerentes que administram suas terras e são responsáveis pelo funcionamento das atividades lá realizadas. Nesses casos, as relações entre os fazendeiros e os trabalhadores não são freqüentes, o que pode torná-los alheios aos conflitos e tensões que ocorrem em sua propriedade. Se os proprietários moram nas fazendas, é estabelecido um contato regular com os trabalhadores. Muitas vezes, os fazendeiros podem ser os agentes do aliciamento (OIT, no prelo).

Residindo ou não nas fazendas, os proprietários concordam com as condições de trabalho e com os mecanismos de coerção exercidos sobre os seus trabalhadores temporários, embora a presença de intermediários contribua para a alegada "ignorância" do proprietário sobre os excessos cometidos contra os trabalhadores.

Nas fazendas maiores, o número de trabalhadores fixos aumenta, podendo contar com uma estrutura sofisticada, o que inclui tecnologia e mão-de-obra especializada em diversas áreas do conhecimento, como agrônomos e veterinários. $\mathrm{O}$ recrutamento dos trabalhadores temporários, nesses casos, poderá ser realizado por um funcionário denominado "empreiteiro".

Embora essas fazendas estejam ligadas ao capitalismo moderno e eficiente, conectado ao mercado internacional, nelas são estabelecidas formas de produção baseadas na desvalorização da vida dos seus trabalhadores, cujos corpos são colocados à disposição do capital e do agronegócio. 
A hierarquia estabelecida no seu interior parece estar organizada de modo a assegurar o controle, o cuidado $e$ o usufruto das vidas nuas ou destituídas de valor dos trabalhadores escravizados, evidenciando a estrutura biopolítica por trás da cadeia de mando dessas propriedades rurais.

Fora das fazendas, a soberania dos fazendeiros é reconhecida pela força política que possuem. Muitos exercem poder e influência em diferentes instâncias da política nacional, seja de forma direta, ocupando efetivamente cargos em Prefeituras, Câmaras Legislativas Municipais, Governos Estaduais e no Congresso Nacional, ou, de forma indireta, por possuir estreitos laços com representantes dos seus interesses nos referidos cargos (OIT, no prelo). Além disso, os fazendeiros podem contar com a conivência da polícia, que pode atuar como parte dos instrumentos de repressão utilizados contra os trabalhadores. ${ }^{9}$ Não são poucos os casos em que autoridades locais, ao invés de registrarem denúncias de abusos sofridos por trabalhadores fugitivos, entregam os trabalhadores novamente aos "gatos" que os contrataram (Figueira, 2004).

Detentores de surpreendente força política e econômica, os fazendeiros personificam o poder soberano, o que lhes garante impunidade e gera a reincidência no crime de redução de pessoas a condições análogas à escravidão. A vida e os corpos dos trabalhadores tornam-se, portanto, o local, por excelência, da sua decisão soberana. Deixá-los morrer, ordenando sua execução ou retirando-lhes as condições mínimas de sobrevivência (água,

9 O sucesso dos fazendeiros que se instalaram no estado do Pará, por exemplo, dependia, em grande medida, da sua capacidade de transformar em seus aliados as polícias militar e civil. As milícias privadas dos fazendeiros são, até hoje, freqüentemente formadas e mantidas com a participação de policiais. As principais vítimas das milícias são trabalhadores rurais, religiosos, ambientalistas, militantes em defesa dos direitos humanos e dirigentes sindicais do campo que procuram defender os direitos daqueles com baixas rendas e submetidos à exploração das mais diversas ordens. Para mais informações, conferir OIT (no prelo), em que a formação do estado do Pará é analisada a partir dos estudos de Nepomuceno (2007) e Figueira (2004). 
A construção da masculinidade e a banalidade do mal

comida, alojamento, cuidados médicos) no local de trabalho, tornam-se "práticas corriqueiras" plenamente justificadas pelas atividades produtivas. Além disso, são práticas também viabilizadas pelo processo de desenraizamento dos trabalhadores que, ao desconectá-los de suas referências sociais e morais, contribui para a desvalorização das suas vidas.

Como mencionado, os "peões de trecho" são emblemas do desenraizamento social. Suas trajetórias tornam-se uma espécie de negação à vida. Cativos da rede do endividamento progressivo $e$ do alcoolismo, bem como submetidos ao isolamento afetivo, econômico e geográfico, eles entram em uma vida sem perspectiva cujo fim pode ser trágico (Figueira, 2004:291). Isso parece transformá-los em indivíduos definidos por Agamben (2002:145) como "incuravelmente perdidos", cujas vidas são "indignas de serem vividas". Para eles, embora não exista constatável anuência à morte, esta pode, muitas vezes, não se chocar contra uma vontade de viver.

A pobreza e a exclusão social que permeiam a vida dos jovens trabalhadores antes de partirem da casa dos pais, aliado ao processo de desenraizamento social e ao contexto da biopolítica moderna, viabilizam a morte e a violência contra os mesmos, sem gerar questionamentos e constrangimentos morais por parte dos que exercem essas ações, exemplificando a "banalidade do mal".

Para os proprietários dos empreendimentos rurais, seu poder soberano autoriza o exercício do mal-banal. Para os funcionários das fazendas, a morte e a violência contra os "peões" são atitudes cobertas por ordens, portanto, justificadas pelo cumprimento ao dever e pela lealdade absoluta ao poder soberano do fazendeiro. Suas ações não parecem impulsionadas por motivos ou interesses pessoais claramente definidos. A maldade exercida, também entre os funcionários, aparece como uma atitude superficial desprovida de reflexão e raízes, pois não se apóia em causas ou estímulos particulares de quem a exerce.

Se a banalidade do mal é passível de ser exercida quando ligada às vidas destituídas de valor político e importância social, a 
escravidão colonial parece ter estabelecido um padrão cultural de exploração e de usufruto dessas vidas. Ao instituir um modo-deprodução que se sustenta na desvalorização e, naquele caso, na desumanização do outro, cria-se um padrão cultural de comportamento norteador das relações hierárquicas baseadas nessa desvalorização. Essa desvalorização política e social da vida viabiliza a submissão dos corpos daqueles considerados sem-valor a condições degradantes de trabalho $e$ a quaisquer formas de violência.

No período colonial, a vida sem valor e, portanto, o corpo a ser colocado à disposição pertencia, especialmente, ao negro africano. Atualmente, a desvalorização da vida não parece estar confinada a uma categoria social específica. Critérios sociais, raciais, regionais e de gênero podem fazer do pobre, do negro, do nordestino e da mulher alvos preferenciais dessa desvalorização, o que é acentuado quando suas vidas são percebidas como parte daquele processo de desenraizamento social.

A violência sexual exercida contra as mulheres também parece evidenciar a banalidade do mal associada ao processo de desenraizamento social. Ao analisar o estupro do ponto de vista das mulheres violentadas e dos estupradores presos, Machado (2000) revela a destituição de valor político e da importância social das mulheres vítimas dessa violência, aos olhos dos estupradores. Para eles, o estupro não passava de um ato sexual banal, sem qualquer excepcionalidade, por isso não entendiam porque estavam presos. Os relatos analisados, de modo geral, falavam da mulher, alvo da sua ação, como alguém desconectada de laços sociais reconhecidos e valorizados por eles, o que justificava a ação. Por não ser percebida como esposa, mãe, filha ou irmã de alguém, preferencialmente, de algum outro homem, seu corpo pôde ser colocado à disposição daqueles que quiseram dele usufruir.

Semelhante à violência exercida contra os trabalhadores escravizados, que inclui violência sexual, como mencionado, a desvalorização das mulheres analisadas por Machado (2000) 
A construção da masculinidade e a banalidade do mal

parece igualmente parte de um cenário maior marcado pela politização da vida. Nele, um poder soberano personificado na figura do estuprador pôde decidir quais vidas deixaram de ser politicamente importantes e quando elas poderiam ser submetidas à violência, sem que isso gerasse questionamentos morais pelos que a exerceram.

O exemplo citado no início do texto sobre a violência sexual exercida contra o trabalhador revela uma importante dimensão da escravidão contemporânea. Obrigar o trabalhador fugitivo a praticar sexo oral em um funcionário da fazenda como forma de castigo parece ir de encontro a um possível argumento sobre a desumanização dos escravos contemporâneos por parte dos que lhe são hierarquicamente superiores. Se fossem considerados mercadorias, o ato, que claramente afeta as noções de virilidade, masculinidade e dignidade dos envolvidos, poderia não ter sido pensado como forma de punição eficaz.

A escolha desse castigo parece demonstrar que funcionários e "peões" compartilham, conscientemente, o mesmo universo de valores, além da mesma condição humana. Trabalhadores submetidos a condições análogas à escravidão podem, futuramente, inserir-se no sistema produtivo das fazendas na condição de fiscal. Além disso, muitos funcionários, inclusive os "gatos", podem ter a mesma origem social dos trabalhadores escravizados.

Nesse sentido, eles conhecem o processo de construção da masculinidade que envolve os jovens escravizados, pois também podem ter vivenciado esse processo. Justamente por conhecê-lo, sabem que valores estão em jogo na vida dos jovens no momento em que foram cooptados para o trabalho na fazenda. É o compartilhar de valores que garantiu escolha de uma forma particularmente eficaz de punição. A violência, também simbólica, presente no ato e no contexto da escravidão contemporânea fere a honra do trabalhador que, submetido a uma posição de completa passividade, foi destituído da possibilidade de realizar o seu papel masculino em vários sentidos. Seja no sentido sexual, 
definido por uma forma considerada ativa de exercer a sexualidade, seja no sentido social e econômico, definido pela sua capacidade de prover uma família pelo próprio trabalho. A vergonha, que acompanhou o trabalhador submetido ao abuso, possivelmente exerceu um impressionante papel no controle das suas ações, tanto no espaço da fazenda, quanto fora.

A eficácia dessa forma de punição também se deveu ao fato dela ter sido exemplar, pois, simbolicamente, podia ser estendida aos demais trabalhadores que compartilhavam aquele complexo de masculinidade. Isso tornou a punição singular e diferente de outros castigos, como as surras exercidas contra os trabalhadores fugitivos e igualmente assistidas por todos. Se as surras podem, de algum modo, reforçar a virilidade dos trabalhadores que a suportam, a violência sexual pode destruí-la, o que afeta a imagem e a honra do trabalhador violentado perante os demais impedindo novas tentativas de fuga.

Essas situações parecem revelar que, na escravidão contemporânea, a politização da vida adquire contornos particulares por estar associada a dois processos aparentemente inerentes à vida desses trabalhadores: o de construção da masculinidade e o de desenraizamento social. $\mathrm{O}$ primeiro possibilita o tráfico interno de pessoas, ao impulsionar a partida dos jovens em busca da realização do papel social masculino que lhes foi culturalmente definido. O segundo é fruto do tráfico e tem por finalidade o trabalho forçado que desconecta os jovens dos laços com a família deixada para trás e com os lugares de origem, apagando, aos poucos, suas referências sociais e morais, $e$ contribuindo para que as suas vidas sejam destituídas de valor.

Compreender tais processos ajuda a pensar ações para a prevenção do trabalho escravo que tenham como foco o jovem trabalhador rural que, potencialmente, pode migrar e acabar submetido à escravidão por dívida, não apenas o trabalhador resgatado das condições análogas à escravidão. São discussões como essa que o texto procurou estimular. 
A construção da masculinidade e a banalidade do mal

\section{Referências bibliográficas}

AgAbem, Giorgio. Homo Sacer: O poder soberano e a vida nua. Belo Horizonte, Editora da UFMG, 2002.

Bignoto, Newtom \& MORAES, Eduardo Jardim. (orgs.) Hannah Arendt: Diálogos, reflexões, memórias. Belo Horizonte, Ed. da UFMG, 2003.

CostA, Patrícia Trindade Maranhão. As Raízes da Congada: A renovação do presente pelos Filhos do Rosário. Tese de Doutorado. Antropologia Social, UnB, 2006.

FigueIRA, Ricardo Rezende. Pisando Fora da Própria Sombra. A escravidão por dívida no Brasil contemporâneo. Rio de Janeiro, Civilização Brasileira, 2004.

MACHADO, Lia Zanotta. Sexo, Estupro e Purificação. Série Antropologia (286), Brasília, Departamento de Antropologia/UnB, 2000, pp.1-38.

MARTINS, José de Souza. Fronteira: A degradação do outro nos confins do humano. São Paulo, HUCITEC, 1997.

Melo, Luís Antônio Camargo. Atuação do Ministério Público do trabalho no Combate ao Trabalho escravo - crimes contra a organização do trabalho e demais crimes conexos. In: Possibilidades Jurídicas de Combate à Escravidão Contemporânea. Brasília, OIT, 2007.

NePOMUCEno, Eric. O massacre - Eldorado dos Carajás: uma história de impunidade. São Paulo, Editora Planeta Brasil, 2007.

ORganizaÇão InTERnACIONAL Do TRABALHO (OIT). Ações Brasileiras no Combate ao Trabalho Escravo. Estudo realizado por Patrícia Trindade Maranhão Costa com a colaboração de Aline Thomé Arruda. OIT-Brasil, no prelo.

Relatório Global do Seguimento da Declaração da OIT sobre Princípios e Direitos Fundamentais no Trabalho. Uma Aliança Global Contra o Trabalho Forçado. Genebra, Secretaria Internacional do Trabalho, Conferência Internacional do Trabalho, 93 ${ }^{\text {a }}$ Reunião, 2005.

SUÁREZ, Mireya. Comunicação oral em agosto de 2008.

WoORTMAnN, Klaas. Com Parente Não se Neguceia. Anuário Antropológico/87, Rio de Janeiro, Editora Tempo Brasileiro, 1990. 